\title{
Media Relations and Corporate Reputations in Corporate Social Responsibility (CSR) Activities of PT. Indonesia Power Semarang Up Generation
}

\author{
Nuriyatul Lailiyah \\ \{nuriyatullailiyah@lecturer.undip.ac.id\} \\ Universitas Diponegoro, Indonesia
}

\begin{abstract}
The use of media relations as part of an effort to communicate corporate social responsibilities (CSR) activities to the public for a high risked company is needed to ensure that the reputation that the company expects is well maintained. In the long term, CSR will provide a profitable business guarantee, not only increasing public trust, strengthening investment, but the implementation of CSR activities will certainly secure the company's business operations so that the company can run operations with the support needed. This article aims to look at corporate media relations activities and their impact on company reputation from the perspective of the surrounding community. The research was conducted using a mixed-method. The data were collected by surveying the community around the company and through in-depth interviews with public relations staff of PT. Indonesia Power Semarang Up Generation. The results showed that apart from media relations activities that were not sufficiently planned, the local community generally considered the company to have carried out CSR which had a positive impact on the interests of the surrounding community. In this situation, direct communication with the public is more effective in enhancing the company's reputation than the use of media relations.
\end{abstract}

Keywords: Media Relations, Corporate Social Responsibility, Reputation, Community

\section{Introduction}

The development of CSR studies has increased sharply in the past few years, CSR is interpreted as a form of business social responsibility and is also perceived as an activity of social generosity. Mohr et al. [1] see CSR as a company's commitment to minimize or eliminate short-term harmful effects and maximize long-term profits that have a positive impact on society. CSR activities can be referred to as business responsibility. CSR is conceptualized as a form of social responsibility that has fundamental benefits for the company, society and the surrounding environment [2][3]. In this context the company uses the concept of CSR not only to build good relations with the government, but also with all relevant stakeholders in order to ensure sustainable business performance (Pakistan Imran Ali). CSR can be defined as a paradigm for overcoming conditions that endanger the company [4].

Based on Clarke [5] and Lantos [6] there are two viewpoints regarding the role of business in society (which leads to different views on CSR) differentiated in. The classic view is based on neoclassical economic theory which defines business activities as purely an 
economy that focuses on profit-seeking, focuses on the benefits of shareholders. On the other hand, Stakeholder Theory, states that companies have social responsibility which requires companies to consider the interests of all parties affected by company business activities.

Iriantara [7] defines media relations as part of external public relations that fosters and develops good relations with the mass media as a means of communication between organizations and the public to achieve organizational goals.

Thus, media relations occupy an important position in the work of a Public Relations because mass media is the goal and controls the information flowing to society in a social system. Function of media relations Johnson and Johnson [8] emphasized that the media has a very important role and function for the company, including:

a) The function of media relations can improve the company's image.

b) Increase public trust in the products and services offered by the company.

c) Increase the point of selling of products and services.

d) Help companies get out of crisis communication.

e) Increasing the relations of various publics, such as government agencies, companies, community organizations, and individuals.

Corporate reputation as described by Fombrun [9] is based on a collective assessment that contains views and beliefs about the company's ability and willingness to meet the interests of the various stakeholders involved. Bromley [10] and Sandberg [11] see reputation as a shared social impression and a consensus on how companies behave in certain situations which is a strong influence on business success. Bennett and Rentschler [12] define reputation as a corporate image and identity related to value considerations, long-term commitment, consistency, firmness and corporate credibility. Marken [13] describes reputation as product and service quality, innovative capabilities, long-term investment plans, company attractiveness, quality control. Marken [14] states in his study that the reputation developed is influenced by the daily activities of the company.

The survey was conducted on residents around the company operating. The number of samples in the study were 51 people who were taken non-randomly to assets the reputation the company has.

\section{Result and Discussion}

The results showed that media relations activities at PT. Indonesia Power Semarang Up Generation was not carried out optimally. Media relations activities were carried out in the form of media gatherings, sending press releases, and interviews. The giving of statements to the media is regulated through a fairly strict procedure to ensure that the company is one voice and provides the right statement to the media.

Performing the PR function using media relations as a strategy is the right decision because the back and forth of the company is very dependent on the harmonization of the relationship between the press and the company. Basically, efforts to build media relations aim to [7]:

a) Maintain neutrality and objectivity towards information or data developing in the mass media. The existence of good relations with the media is expected to help inform news that is fair, balanced and beneficial to the company or organization involved.

b) Obtain the proper means for the widest possible publication of activities and policies taken by the company that are deemed good for the public to know. 
c) It is undeniable that the presence of good media relations will generate feedback and responses from the public as reference data or a basis for evaluating the activities of an organization or company.

d) Furthermore, the purpose of relations with the media is to foster trust so that it can create a good relationship on an ongoing basis between the company and the press.

Companies are more likely to show better communication performance when dealing with communities. This can be seen from the respondents' responses to the questions posed regarding their views on the company's reputation.

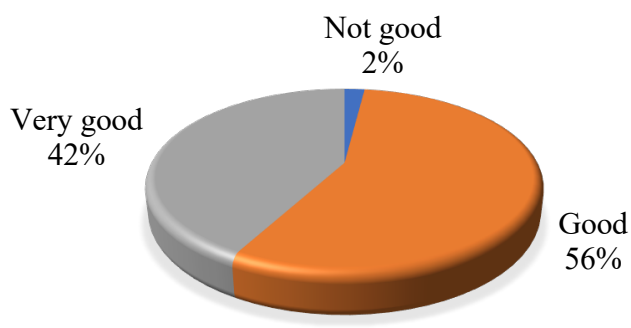

Fig. 1. The community opinion on the trust the company has given to the community.

Only $2 \%$ of respondents stated that the company did not trust the surrounding community. This point is important because it shows the quality of communication that occurs between the company and the community. As many as $98 \%$ of the respondents think that the company has given trust to the community. In a relationship, trusting a communication partner and feeling trusted will encourage transparent and mutually supportive communication. Trust allows the parties involved to help each other in their respective capacities, which in turn makes communication goals achieved.

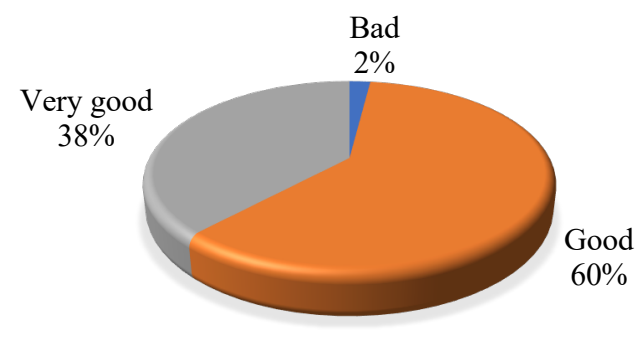

Fig. 2. Community opinion about the company's commitment in carrying out the sustainability of the CSR program.

The positive view was not much different when respondents were asked their opinion regarding the company's commitment to carrying out the sustainability of the CSR program. Only $2 \%$ of respondents said they were bad about this. This shows that respondents see the company as having a long-term commitment to improving the quality of life of the communities around which the company operates.

Respondents also considered that the company's CSR implementation was well managed (58\%). In fact, as many as $40 \%$ of respondents answered that the company's CSR implementation is running very well. Only $2 \%$ of respondents thought CSR activities were 
going badly. The positive responses cannot be separated from the company's ability to communicate with the community.

According to Rudito and Famiola [15], the CSR program is communicated by the company's public relations officer (PRO). In CSR communication activities, it must be as optimal as possible to the audience so that they are aware and aware of the CSR program being implemented. PROs who play a role in communicating CSR must not cover up the bad CSR program being implemented, because it will have an impact on changing messages so that it will not be effective for stakeholders and result in not achieving the goals of the CSR program and there is no reciprocal relationship between companies and stakeholders.

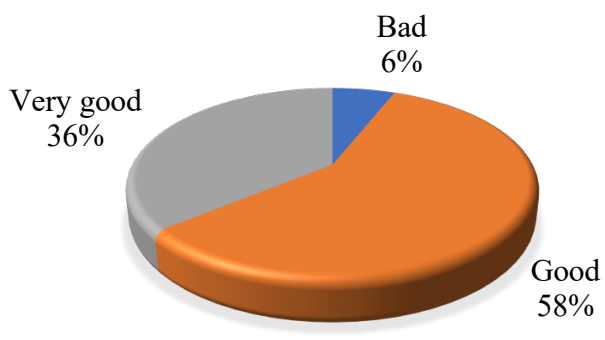

Fig. 3. Community opinion on company operations that do not endanger (security) the surrounding community.

Only $6 \%$ of respondents stated that the company's operations in their environment were dangerous. The rest saw the company's existence as a positive thing in their environment. Among the real positive impacts is that the company recruits local workers to be employed. This is proof of the company's commitment and trust in the community's ability. In employing local communities, companies basically do not only take advantage of the community's capabilities and potentials. The company itself also provides assistance in ensuring that the competence of local people employed meets the company's needs.

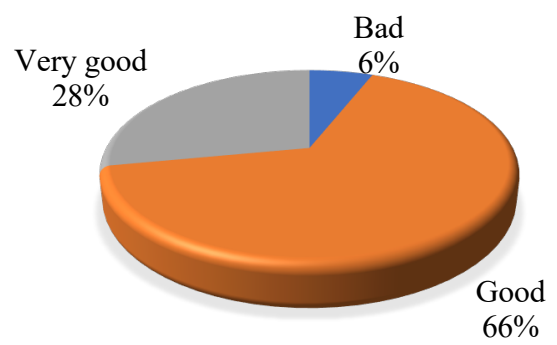

Fig. 4. Community opinion on the availability of the company in distributing business profits to the communities around where the company operates.

The diagram above shows that the company's willingness to share profits on the company's operating environment is perceived well by the local community. Only $6 \%$ thought the company was not good enough to share profits with local communities. Respondents also rated the company as having good concern for the environment (68\%). As many as $29 \%$ of respondents even think that the company's concern for the environment is very good. 
Meanwhile, 3\% of respondents thought that the company did not care enough about the environment.

The concept and objectives of CSR which are carried out are in line with Kotijah [16] that social and environmental responsibility aims at realizing sustainable economic development in order to improve the quality of life and the environment that is beneficial to the company itself, the local community, and society at large. This is in order to support the establishment of a corporate relationship that is harmonious, balanced and in accordance with the environment, values, norms and culture of the local community. Companies need to respond well, and see social problems that have not been handled properly, through CSR activities the company partners with the government to help alleviate poverty, create community independence, cooperate and be committed to maintaining environmental balance and caring for the preservation of local culture.

In general, respondents saw that PT. Indonesia Power Semarang Up Generation has a role and contribution to advance the electric energy industry sector in Indonesia. Only $4 \%$ of respondents thought the company's role was not good enough. Meanwhile, $62 \%$ think it is good and even $34 \%$ think the role of the company is very good in advancing the electric energy industry sector.

\section{Conclusion}

The results showed that in general the community's perception of PT. Indonesia Power Semarang Up Generation is very positive considering that negative perceptions of the company's reputation are interpreted negatively by not more than $6 \%$ of respondents.

On the other hand, media relations activities are carried out as if it were business as usual. there is no visible innovation to maximize media relations as a means of communicating to various stakeholders. If it is seen only from the quality of communication with the community, media relations do not seem necessary and in fact does not show any contribution in building the company's reputation in the eyes of the community. However, when viewed in a broader framework, media relations can carry out corporate communications to a wider and wider range of publics such as the community, government, and so on. Because the company has not only the community as part of its stakeholders.

\section{References}

[1] L. A. Mohr, D. J. Webb, and K. E. Harris, "Do consumers expect companies to be socially responsible? The impact of corporate social responsibility on buying behavior," J. Consum. Aff., vol. 35 , no. 1, pp. 45-72, 2001.

[2] N. N. N. Ahmad, M. Sulaiman, and D. Siswantoro, "Corporate social responsibility disclosure in Malaysia: An analysis of annual reports of KLSE listed companies," Int. J. Econ. Manag. Account., vol. 11, no. 1, 2003.

[3] J. Andriof and S. Waddock, "Unfolding stakeholder engagement," Unfolding Stakehold. Think. Theory, Responsib. Engagem., vol. 1, no. 121, pp. 17-42, 2002.

[4] A. Crane, A. McWilliams, D. Matten, J. Moon, and D. S. Siegel, The Oxford handbook of corporate social responsibility. Oxford Handbooks, 2008.

[5] T. Clarke, "The stakeholder corporation: A business philosophy for the information age," Long Range Plann., vol. 31, no. 2, pp. 182-194, 1998.

[6] G. P. Lantos, "The boundaries of strategic corporate social responsibility," J. Consum. Mark., 2001. 
[7] Y. Iriantara and S. Rema Karyanti, Media relations: Konsep, pendekatan dan Praktik. Simbiosa Rekatama Media, 2005.

[8] D. W. Johnson and R. T. Johnson, “Cooperative learning,” Encycl. peace Psychol., 2011.

[9] C. Fombrun, Corporate reputation: Definitions, antecedents, consequences. Oxford University Press Oxford, UK, 2012.

[10] D. Bromley, "Comparing corporate reputations: League tables, quotients, benchmarks, or case studies?," Corp. Reput. Rev., vol. 5, no. 1, pp. 35-50, 2002.

[11] K. Sandberg, "Kicking the tires of corporate reputation," Harvard Manag. Commun. Lett., vol. 5, no. 1, pp. 3-4, 2002.

[12] R. Bennett and R. Rentschler, "Foreword by the guest editors," Corp. Reput. Rev., vol. 6, no. 3, pp. 207-210, 2003.

[13] G. A. Marken, "One-minute corporate reputation management," Public Relations Q., vol. 47, no. 4 , p. $21,2002$.

[14] G. A. Marken, "Reputation management starts at home: One day at a time," Public Relations Q., vol. 49, no. 2, pp. 35-36, 2004.

[15] B. Rudito and M. Famiola, "CSR (Corporate Social Responsibility)," 2013.

[16] S. Kotijah, "Advancing Corporate Social Responsibility of Mining." 